\title{
Extracellular Vesicles Derived from Lactobacillus plantarum Increase BDNF Expression in Cultured Hippocampal Neurons and Produce Antidepressant-like Effects in Mice
}

\author{
Juli Choi ${ }^{1}$, Yoon-Keun Kim ${ }^{2}$ and Pyung-Lim Han ${ }^{1,3 *}$ \\ ${ }^{1}$ Department of Brain and Cognitive Sciences, Ewha Womans University, Seoul 03760, ${ }^{2}$ MD Healthcare Inc., Seoul 03923, \\ ${ }^{3}$ Department of Chemistry and Nano Science, Ewha Womans University, Seoul 03760, Korea
}

\begin{abstract}
Gut microbiota play a role in regulating mental disorders, but the mechanism by which gut microbiota regulate brain function remains unclear. Gram negative and positive gut bacteria release membrane-derived extracellular vesicles (EVs), which function in microbiota-host intercellular communication. In the present study, we investigated whether Lactobacillus plantarum derived EVs ( $L$-EVs) could have a role in regulating neuronal function and stress-induced depressive-like behaviors. HT22 cells treated with the stress hormone glucocorticoid (GC; corticosterone) had reduced expression of $B d n f$ and Sirt1, whereas $L$-EV treatment reversed GC-induced decreased expression of $B d n f$ and Sirt1. The siRNA-mediated knockdown of Sirt 1 in HT22 cells decreased Bdnf4, a splicing variant of $B d n f$, and $C r e b$ expression, suggesting that Sirtl plays a role in $L$-EV-induced increase of BDNF and CREB expression. Mice exposed to restraint for 2-h daily for 14 days (CRST) exhibited depressive-like behaviors, and these CRST-treated mice had reduced expression of $B d n f$ and $N t 4 / 5$ in the hippocampus. In contrast, $L$-EV injection prior to each restraint treatment blocked the reduced expression of $B d n f$ and $N t 4 / 5$, and stress-induced depressive-like behaviors. Furthermore, $L$-EV treatment in CRST-treated mice also rescued the reduced expression of $B d n f$, and blocked stress-induced depressive-like behaviors. These results suggest that Lactobacillus derived EVs can change the expression of neurotropic factors in the hippocampus and afford antidepressant-like effects in mice with stress-induced depression.
\end{abstract}

Key words: Extracellular vesicles, Lactobacillus plantarum, BDNF, Antidepressant-like effects

\section{INTRODUCTION}

Gut microbiota have an influence on cognition and behavior [1,

Received September 22, 2018, Revised March 25, 2019

Accepted March 28, 2019

* To whom correspondence should be addressed.

TEL: 82-2-3277-4130, FAX: 82-2-3277-3419

e-mail:plhan@ewha.ac.kr
2]. Recent studies have reported that patients with depression had reduced composition of Bacteroidetes, Bifidobacterium and Lactobacillus in the gut microbial flora [3-5]. Supplement of probiotic capsules containing Lactobacillus acidophilus, Lactobacillus casei, and Bifidobacterium bifidum for 8 weeks in depression patients produced beneficial effects on depressive symptoms [6]. Ingestion of fermented milk containing Lactobacillus casei diminished anxiety and physical symptoms of medical students under academic examination [7]. Studies in animal models also supported the
Copyright $\odot$ Experimental Neurobiology 2019. www.enjournal.org
This is an Open Access article distributed under the terms of the Creative Commons Attribution Non-Commercial License (http://creativecommons.org/licenses/by-nc/4.0) which permits unrestricted non-commercial use, distribution, and reproduction in any medium, provided the original work is properly cited. 
beneficial effects of Lactobacillus on brain function. Supplement of Lactobacillus rhamnosus in mice displaying stress-induced depressive symptoms produced antidepressant effects and reduced the level of stress-induced increased corticosterone levels $[8,9]$. Ingestion of Lactobacillus helveticus in rats with chronic restraint stress improved anhedonia and suppressed anxiety [10]. The level of Lactobacillus in fecal samples of mice was correlated with stress-induced depressive-like behavior, whereas depressivelike symptoms were ameliorated by treatment with its metabolite, kynurenine [11]. Collectively, these studies consistently support the notion that various strains of Lactobacillus produce beneficial effects on depressive symptoms of depression patients or stressinduced depressive-like behaviors in animal models.

Several studies have attempted to explore the mechanisms of how gut microbiota influence brain function. Gut microbiota appear to maintain host homeostasis by communicating directly and indirectly with the nerve system $[1,12,13]$. Several underlying mechanisms have been proposed to explain how gut bacteria affect neural function; (i) bacterial metabolites including short chain fatty acids, carbohydrates, bile acids [14, 15], and kynurenine [11], (ii) cytokines such as IL-6, MCP-1, TNFa, and INFa which were secreted from monocytes after stimulation with gut microbiota [16-18], and (iii) bacterial neurometabolites including dopamine, GABA, tryptophan or 5-HT precursors [19-21]. These products and metabolites are believed to enter the circulatory system and affect brain function. In contrast to this view, (iv) retrograde transport of bacterial metabolites directly through the vagus nerves innervating gut epithelial cells could occur and thereby change neural function [22-24].

Recent studies demonstrated that gut bacteria release membrane-derived extracellular vesicles (EVs) [25]. EVs carry nucleic acids, lipids, proteins, and bacterial metabolites, which can affect various cellular pathways in the host [26]. For example, Akkermansia muciniphila derived EVs produced protective effects on LPS-induced intestinal permeability changes through increasing phosphorylation of AMPK and tight junctions [27] and attenuate colitis-induced inflammation [28]. EVs carrying capsular polysaccharide (PSA) derived from Bacteroides fragilis prevented colitis by enhancing immunomodulatory effects [29]. Thus, EVs derived from specific strains of bacteria could function as novel mechanisms mediating physiological effects of the microbiota on the host. However, it is unknown whether bacteria-derived EVs can directly affect brain function.

Lactobacillus plantarum is a gram-positive bacterium that is present in dairy, fermented vegetables, and the gastrointestinal tract $[30,31]$. L. plantarum is known to function as an immunomodulator on human colon cancer cells [32]. Recent studies have reported the beneficial protection of $L$. plantarum on stressinduced behavior dysfunction. Administration of living or dead $L$. plantarum improved cognitive deficits against aluminum-induced brain and liver injuries in mice [33] and attenuated anxiety behavior of stressed zebrafish [34]. Administration of L. plantarum MTCC 9510 reduced oxidative stress markers and inflammatory cytokines in the brain and serum and improved stress-induced behavioral despair [35].

In this study, we investigated whether EVs produced by L. plantarum could induce changes in the expression of BDNF and improve stress-induced depressive-like behaviors.

\section{MATERIALS AND METHODS}

\section{Preparation of EVs from Lactobacillus plantarum}

Bacterial culture and EV isolation were carried out as described previously [36]. Lactobacillus plantarum (KCTC 11401BP, GenBank accession No. GQ336971) was cultured in MRS broth (MB Cell, CA, USA) for $18 \mathrm{~h}$ at $37^{\circ} \mathrm{C}$ with gently shaking (150 rpm). When the optical density of the culture reached 1.0 at $600 \mathrm{~nm}$, bacteria were pelleted at $10,000 \times \mathrm{g}$ for $20 \mathrm{~min}$ and the supernatant was passed through a $0.22-\mu \mathrm{m}$ bottle-top filter (Corning, NY, USA) to remove remaining cells. The filtrate was concentrated through a MasterFlex pump system (Cole-Parmer, IL, USA) using a $100 \mathrm{KDa}$ Pellicon 2 Cassette filter membrane (Merck Millipore, MA, USA) and subsequently passed through a $0.22-\mu \mathrm{m}$ bottle-top filter (Corning, NY, USA). The extracellular vesicles were obtained by ultracentrifugation at $150,000 \times \mathrm{g}$ for $3 \mathrm{~h}$ at $4^{\circ} \mathrm{C}$. Protein concentration was measured with BCA assay (Thermo Fisher Scientific, MA, USA) and the collected EV fractions were stored at $-80^{\circ} \mathrm{C}$ until use. The size of purified $L$-EVs was in the range of $20 \sim 100$ $\mathrm{nm}$ in diameter, which was described recently [36].

\section{HT22 cell culture and L. plantarum-EVs (L-EVs) treatment}

HT22 cells were cultured as described previously $[37,38]$. In brief, HT22 cells were grown in Dulbeccós modified Eagles medium (DMEM; LM001-05, Welgene, Gyeongan-si, Korea) containing $10 \%$ heat-inactivated fetal bovine serum (FBS; FB02-500, Serum Source International, Charlotte, NC, USA) and penicillin (20 units/ml)/ streptomycin (20 mg/ml) (LS020-02, Welgene) at $37^{\circ} \mathrm{C}$ and $5 \% \mathrm{CO}_{2}$ supply conditions. At 70 80\% confluency, HT22 cells were trypsinized and counted using a trypan blue (0.4\%) staining method. They were plated at a density of $1.0 \times 10^{5}$ cells/ well on a 6-well plate (SPL Life Science, Pocheon-si, Gyeonggido), or $1.0 \times 10^{6}$ cells on a $100-\mathrm{mm}$ dish in DMEM media supplemented with 10\% FBS and antibiotics. After $24 \mathrm{~h}$ of culture, cells were treated with glucocorticoid (GC; corticosterone, $400 \mathrm{ng} / \mathrm{ml}$ ) 
or $L$-EV $(20 \mu \mathrm{g} / \mathrm{ml})$ in DMEM media supplemented with 1\% FBS for $24 \mathrm{~h}$. The dose of GC and $L-\mathrm{EV}$ was chosen based on previous studies $[36,37]$.

Transfection of siRNA into the HT22 cells was performed as described previously $[37,39]$. HT22 cells were plated at a concentration of $1.0 \times 10^{5}$ cells/well in DMEM supplemented with $10 \%$ FBS in a 6-well plate (SPL Life Science). After $24 \mathrm{~h}$, the media was changed with DMEM containing 1\% FBS and siRNA was transfected using Lipofectamine-2000 (13778-075; Invitrogen). To prepare the siRNA and Lipofectamine-2000 mixture, $20 \mu \mathrm{M}$ siRNA (3 $\mu$; final concentration, 50 pM) and Lipofectamine-2000 (9 $\mu$ l; final concentration, $7.5 \mu \mathrm{l} /$ well) were separately diluted in $150 \mu \mathrm{l}$ of Opti-MEM ${ }^{\circledR}$ Medium (31985070, Gibco, Thermo Fisher Scientific, Paisley, Scotland, UK). Each mixture was diluted at 1:1 ratio, mixed slowly and then incubated for $5 \mathrm{~min}$ at room temperature. The siRNA and Lipofectamine-2000 mixture (250 $\mu \mathrm{l} /$ well) was carefully dripped onto HT22 cells while culturing in fresh DMEM containing $1 \%$ FBS with or without $20 \mu \mathrm{g} /$ well of $L$-EVs. They were then incubated for $24 \mathrm{~h}$. Sirt1-siRNA was purchased from Bioneer (\#1452517).

\section{Animals, restraint and L-EV treatment}

Mice were treated with restraints as described previously [40,41]. Male C57BL/6J mice (7-weeks old) were purchased from Daehan BioLink, Inc. (Eumsung, Chungbuk, Korea). Mice were housed in pairs per cage allowing an ad libitum access to water and food at a temperature $\left(23^{\circ} \mathrm{C}\right)$ and humidity (50 60\%)-controlled room under a 12-h light/dark cycle (lights on at 07:00 19:00 h). Animals were handled in accordance with the animal care guidelines of Ewha Womans University and restraint treatment procedures in this study were approved by the Ewha Womans University Animal Care and Use Committee (IACUC 15-012). To deliver restraint, mice were placed in a 50-ml polypropylene tube carrying many punched holes for ventilation and were restrained for 2-h daily for 14 days. Control mice housed in pairs were maintained in home cages without disturbance.

$L$-EVs were administrated in mice in the following ways. $L$-EVs at a dose of $0.1 \mu \mathrm{g} / \mathrm{kg}$ each diluted in saline were intraperitoneally injected into a mouse at a volume of $100 \mu \mathrm{l} 30 \mathrm{~min}$ prior to restraint treatment and after the 14 days of stress session, the daily $L$-EV injection was continued until the behavioral tests were completed (Exp. 1). L-EV treatment during the post-stress period was conducted in mice that were exposed to $2 \mathrm{~h} \times 14 \mathrm{~d}$ restraint treatment (Exp. 2). For the post-stress period, $L$-EVs were intraperitoneally injected at a volume of $100 \mu \mathrm{l}$ containing increasingly higher doses; $0.1 \mu \mathrm{g} / \mathrm{kg}$ for the first 5 days, $0.18 \mu \mathrm{g} / \mathrm{kg}$ for the following 2 days, and $0.27 \mu \mathrm{g} / \mathrm{kg}$ for the final 7 days. Imipramine hydrochlo- ride (IMI; I0899, Sigma) at a dose of $20 \mathrm{mg} / \mathrm{kg}$ was intraperitoneally injected at a volume of $100 \mu \mathrm{l}$ for the indicated days.

\section{Quantitative real-time PCR}

Quantitative real-time PCR (qPCR) analysis was carried out as described previously $[40,41]$. Briefly, hippocampus tissue was obtained and ground using pellet pestles (Z359971, Sigma-Aldrich) in TRI-zol reagent (15596-018, Invitrogen). Harvested HT22 cells were homogenized with TRI-zol reagent. Total RNA was isolated from homogenates and eluted in RNase free water (129112, Qiagen, Hilden, Germany). Two $\mu$ g of total RNA was treated with DNase I to remove genomic DNA contamination and then converted to cDNA using a reverse transcriptase system (Promega, Madison, WI, USA).

Four $\mu \mathrm{l}$ of $1 / 8$ diluted cDNA, $10 \mu$ of $2 \mathrm{X}$ iQTM SYBR Green Supermix (Bio-Rad Laboratories, Foster City, CA, USA), and $1 \mu \mathrm{l}$ each of $5 \mathrm{pmol} / \mu \mathrm{l}$ forward and reverse primers were mixed to a total volume of $20 \mu \mathrm{l}$. The $\mathrm{qPCR}$ reaction was carried out using the CFX 96 Real-Time PCR System Detector (Bio-Rad Laboratories). The transcript expression levels were normalized relative to Gapdh and $L 32$ levels.

The primers used in this study were: $\mathrm{t} B d n f$ (total form), forward 5'-TGGCTGACACTTTTGAGCAC-3' and reverse 5'-GTTTGCGGCATCCAGGTAAT-3'; Bdnf1, forward 5'-CCTGCATCTGTTGGGGAGAC-3' and reverse 5'-GCCTTGTCCGTGGACGTTTA-3'; Bdnf4, forward 5'-CAGAGCAGCTGCCTTGATGTT-3' and reverse 5'-GCCTTGTCCGTGGACGTTTA-3'; Creb1, forward 5'-GAGGCAGCAAGAGAATGTCG-3' and reverse 5'-CCAGTCCATTCTCCACCGTA-3'; Hdac2, forward 5'- GGGACAGGCTTGGTTGTTTC-3' and reverse 5'-GAGCATCAGCAATGGCAAGT-3'; $N t 3$, forward 5' -TACTACGGCAACAGAGACG-3' and reverse 5'-GTTGCCCACATAATCCTCC-3'; Nt4/5, forward 5'-AGCGTTGCCTAGGAATACAGC-3' and reverse 5'-GGTCATGTTGGATGGGAGGTATC-3'; Sirt1, forward 5'-GATCCTTCAGTGTCATGGTTC-3' and reverse 5'-ATGGCAAGTGGCTCATCA-3'; Trk $b$, forward 5'-AAGGACTTTCATCGGGAAGCTG-3' and reverse 5'TCGCCCTCCACACAGACAC-3'; Gapdh, forward 5'-AGAAGGTGGTGAAGCAGGCATC-3' and reverse 5'CGAAGGTGGAAGA GTGGGAGTTG-3'; L32, forward 5'GCTGCCATCTGTTTTACGG-3' and reverse 5-TGACTGGTGCCTGATGAACT-3'

\section{Western blot analysis}

Western blot analysis was carried out as described previously [40]. HT22 cells were washed with 1X PBS (137 mM NaCl, 2.7 $\mathrm{mM} \mathrm{KCl}, 10 \mathrm{mM} \mathrm{Na}_{2} \mathrm{HPO}_{4}, 1.8 \mathrm{mM} \mathrm{KH}_{2} \mathrm{PO}_{4}$ ) and harvested. Harvested HT22 cells or hippocampal tissue was homogenized in homogenization buffer (50 mM Tris-HCl, pH 8.0, $150 \mathrm{mM} \mathrm{NaCl}$, 
$1 \%$ Nonidet P-40, 0.1\% SDS, and 0.1\% sodium deoxycholate) containing a protease inhibitor cocktail (Roche) by sonicating on ice using an Epishear probe sonicator, with two rounds of 15-sec pulses and 30 -sec rest intervals at $40 \%$ power outlet (Active Motif). The supernatant of homogenates was obtained after centrifugation at $13,000 \times \mathrm{g}$ at $4{ }^{\circ} \mathrm{C}$ for $15 \mathrm{~min}$.

The amount of protein was determined by the Bradford method (500-0006, Bio-Rad Laboratories). Twenty $\mu \mathrm{g}$ of tissue or cell sample was mixed with $6 \mathrm{X}$ gel loading buffer and boiled for $5 \mathrm{~min}$. The proteins were resolved on SDS-PAGE and transferred onto PVDF membrane using Trans-Blot ${ }^{\circledR} \mathrm{SD}$ semi-dry Electronic transfer cell and power supply system (1703848, Bio-Rad Laboratories). The blots were incubated with $5 \%$ skim milk or $1 \%$ bovine serum albumin (BSA) in 1X TBST (150 mM NaCl, 50 mM Tris- $\mathrm{HCl}, \mathrm{pH}$ 7.4, 0.1\% Tween 20) to block a non-specific binding. Blots were incubated with a primary antibody in blocking solution followed by a secondary antibody in IX TBST. Specific bands were visualized using Enhanced ChemiLuminescence (ECL)TM Western Blot Analysis System (RPN2109, Amersham, GE Healthcare, UK). Quantification of blot images was processed using the Image-ProPremier 6.0 software (MediaCybernetics, Rockville, MD, USA).

The primary antibodies used were: anti-proBDNF (ANT-006; 1:1,000, Alomone Labs, Hadassah Ein Kerem, Jerusalem, Israel), BDNF (ab108319; 1:2,000, Abcam, Cambridge, UK), and anti- $\beta$ actin (sc-47778; 1:1,000, Santa Cruz). The secondary antibodies used were: anti-mouse IgG-HRP (GTX213111-01; 1:1,000, GeneTex, Irvine, CA, USA) and anti-rabbit IgG-HRP (GTX213110-01; 1:1,000, Gene'Tex).

\section{Behavioral tests}

The behavioral tests were carried out as described previously [40, 41]. Mice were acclimated in the testing room for at least $30 \mathrm{~min}$ prior to the start of each behavioral test. All behavioral tests were performed in the light cycle phase ( 9 a.m. 3 p.m.) and monitored with a computerized video tracking system (SMART; Panlab S.I., Barcelona, Spain) or a webcam recording system (HD Webcam C210, Logitech, Newark, CA, USA).

\section{Sociability test}

The sociability test was performed as described previously [40, 42]. Briefly, the U-shaped two-choice field was prepared by partitioning an open field $\left(40 \times 40 \mathrm{~cm}^{2}\right)$ with a wall $(20$-cm wide and 20 $\mathrm{cm}$ high). Circular grid cages (12 $\mathrm{cm}$ in diameter $\times 33 \mathrm{~cm}$ height) were presented on each side of the U-shaped two-choice field. For habituation, a subject mouse was allowed to freely explore the U-shaped two-choice field with empty circular grid cages on each side for $5 \mathrm{~min}$ and returned to the home cage. After $10 \mathrm{~min}$, a social target mouse was loaded to a circular grid cage at one side and the subject mouse was placed in the center of the U-shaped two-choice field where the subject mouse was able to see both grid cages. The subject mouse was allowed to explore both fields for 10 min while the trajectory spent in the fields was recorded by a video tracking system (SMART, Panlab S.I.) The field with a circular grid cage carrying a social target mouse and the field containing an empty circular grid cage were defined as the target field and nontarget field, respectively. Social target mice with same age and sex as the subject mice were prepared. Social targets had never been exposed to subject mice from the acclimation stage.

\section{Tail suspension test (TST)}

The tail suspension test (TST) was carried out as described previously [40]. Mice were suspended individually by fixing their tails with adhesive tape to the ceiling of a shelve $50 \mathrm{~cm}$ above the bottom floor. The subject mouse was suspended for $6 \mathrm{~min}$ and the $\mathrm{cu}-$ mulative immobility time was measured. Behavioral performances were recorded with a webcam recording system (HD Webcam C210, Logitech) and subsequently analyzed.

\section{Forced swim test (FST)}

The forced swim test was performed as described previously [40]. Mice were placed in a Plexiglas cylinder $(15 \mathrm{~cm}$ in diameter $\times 27$ $\mathrm{cm}$ height) holding water at $24^{\circ} \mathrm{C}$ with a depth of $15 \mathrm{~cm}$. Mice were placed in the cylinder for $6 \mathrm{~min}$ and the cumulative immobility time was measured for the final $5 \mathrm{~min}$. Immobility was defined as the time when a mouse was floating with all limbs motionless. The performance during the test was recorded using a webcam recording system and then analyzed.

\section{Statistical analysis}

Multiple comparisons were performed by one-way ANOVA followed by the Newman-Keuls post hoc test or two-way ANOVA followed by the Bonferroni post hoc test. All data are represented as mean \pm SEM, and statistical significance was accepted at the $5 \%$ level.

\section{RESULTS}

\section{Lactobacillus plantarum-derived EVs (L-EVs) increased the expression of BDNF in HT22 cells}

Administration of microbiota products in mice increased BDNF in hippocampus $[13,43]$. Treatment with probiotics mixture in aged rats increased BDNF levels in the hippocampus [44]. Administration of a probiotic formulation (Lactobacillus helveticus and Bifidobacterium longum mix) in mice rescued stressed-induced 
abnormal brain plasticity and reversed the reduction of neurogenesis and BDNF levels [45]. Therefore, we investigated whether treatment with $L$-EVs in neuronal cells could induce changes in the expression of BDNF and its related factors. The hippocampal cell line HT22 cells treated with glucocorticoid (GC; corticosterone, $400 \mathrm{ng} / \mathrm{ml})$ had decreased expression of total $B d n f(\mathrm{t} B d n f)$ and the BDNF splicing variants $B d n f 1, B d n f 4$, and $N g f$ compared with that of untreated control HT22 cells. In contrast, $L$-EV treat-
A $\begin{array}{ll}\square \mathrm{CON}+\mathrm{veh} & \square \mathrm{GC}+\mathrm{veh} \\ \square \mathrm{CON}+L-\mathrm{EV} & \square \mathrm{GC}+L-\mathrm{EV}\end{array}$

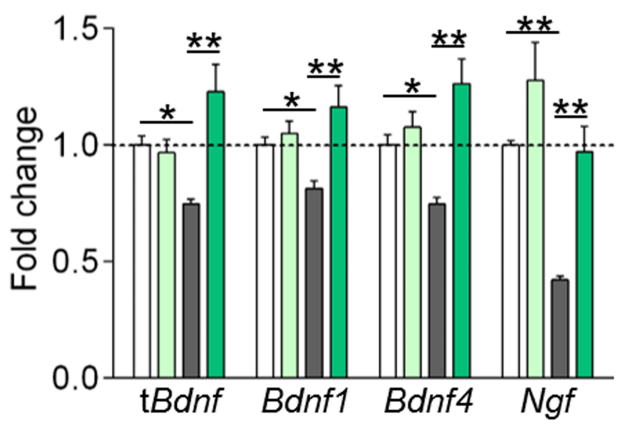

B
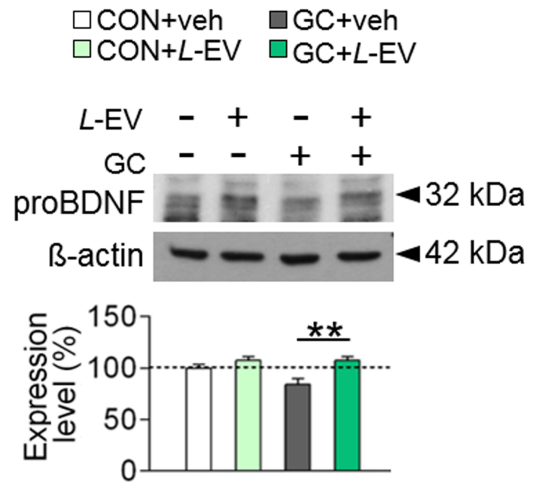

siRNA-Sirt1
C $\begin{array}{ll}\square C O N+v e h & \square G C+v e h \\ \square C O N+L-E V & \square G C+L-E V\end{array}$

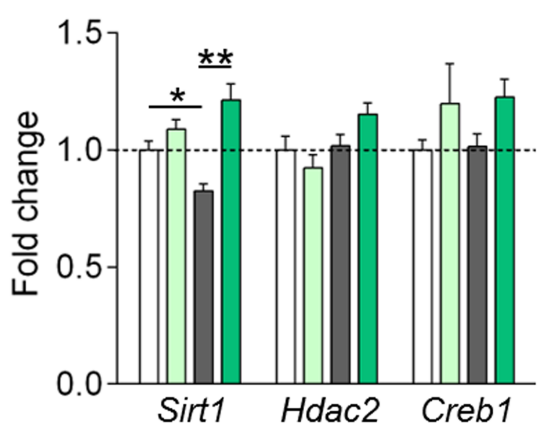

D

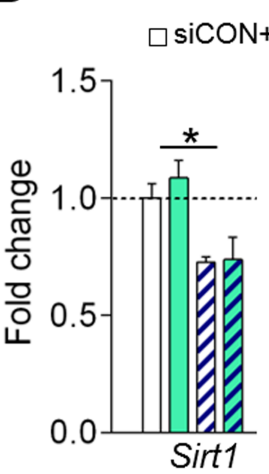

E
Z siSirt1+veh

siSirt1+L-EV

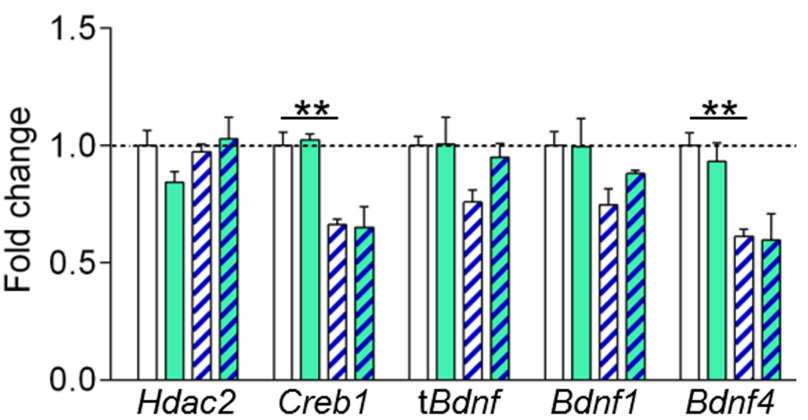

Fig. 1. L. plantarum-derived EVs ( $L$-EVs) increased BDNF expression in HT22 cells. (A) Expression levels of t $B d n f, B d n f 1, B d n f 4$, and $N g f$ in cultured HT22 cells in the presence of GC $(400 \mathrm{ng} / \mathrm{ml}), L$-EV $(20 \mu \mathrm{g} / \mathrm{ml})$ or $\mathrm{GC}+L$-EV for $24 \mathrm{~h}(\mathrm{n}=8 \sim 12$ per group). Two-way ANOVA followed by Bonferroni post hoc test $\left(\mathrm{t} B d n f, \mathrm{~F}_{(1,37)}=0.0052\right.$ and $\mathrm{p}=0.9429$ for $\mathrm{GC}$ main effect, $\mathrm{F}_{(1,37)}=11.19$ and $\mathrm{p}=0.0019$ for $L$-EV main effect, and $\mathrm{F}_{(1,37)}=14.75$ and $\mathrm{p}=0.0005$ for $\mathrm{GC} \times L$-EV; $B d n f 1, \mathrm{~F}_{(1,32)}=1.390$ and $\mathrm{p}=0.2471$ for $\mathrm{GC}$ main effect, $\mathrm{F}_{(1,32)}=13.60$ and $\mathrm{p}=0.0008$ for $L$-EV main effect, and $\mathrm{F}_{(1,32)}=7.166$ and $\mathrm{p}=0.0116$ for $\mathrm{GC} \times L$-EV; $B d n f 4, \mathrm{~F}_{(1,35)}=0.2697$ and $\mathrm{p}=0.6068$ for $\mathrm{GC}$ main effect, $\mathrm{F}_{(1,35)}=22.60$ and $\mathrm{p}<0.0001$ for $L$-EV main effect, and $\mathrm{F}_{(1,35)}=12.49$ and $\mathrm{p}=0.0012$ for $\mathrm{GC} \times L-\mathrm{EV} ; \mathrm{Ngf}, \mathrm{F}_{(1,34)}=27.95$ and $\mathrm{p}<0.0001$ for $\mathrm{GC}$ main effect, $\mathrm{F}_{(1,34)}=24.33$ and $\mathrm{p}<0.0001$ for $L$-EV main effect, and $\mathrm{F}_{(1,34)}=2.639$ and $\mathrm{p}=0.1135$ for $\mathrm{GC} \times L$ $\mathrm{EV})$. (B) Western blot data showing the expression level of proBDNF in HT22 cells treated with GC (400 ng/ml), $L$-EV $(20 \mu \mathrm{g} / \mathrm{ml}) \mathrm{or} \mathrm{GC}+L$-EV for $24 \mathrm{~h}$ ( $\mathrm{n}=6$ per group). Two-way ANOVA followed by Bonferroni post hoc test $\left(\mathrm{F}_{(1,20)}=14.19\right.$ and $\mathrm{p}=0.0012$ for $\mathrm{GC}$ main effect, $\mathrm{F}_{(1,20)}=3.819$ and $\mathrm{p}=0.0648$ for $L$-EV main effect, and $\mathrm{F}_{(1,20)}=3.819$ and $\mathrm{p}=0.0648$ for $\mathrm{GC} \times L$-EV). (C) Expression levels of Sirt1, Hdac2, and Creb1 in HT22 cells treated with GC (400 $\mathrm{ng} / \mathrm{ml}), L$-EV $(20 \mu \mathrm{g} / \mathrm{ml})$ or $\mathrm{GC}+L$-EV for $24 \mathrm{~h}\left(\mathrm{n}=6 \sim 10\right.$ per group). Two-way ANOVA followed by Bonferroni post hoc test (Sirt1, $\mathrm{F}_{(1,27)}=0.0168 \mathrm{and}$ $\mathrm{p}=0.8979$ for $\mathrm{GC}$ main effect, $\mathrm{F}_{(1,27)}=65.48$ and $\mathrm{p}<0.0001$ for $L$-EV main effect, and $\mathrm{F}_{(1,27)}=22.96$ and $\mathrm{p}<0.0001$ for $\mathrm{GC} \times L-\mathrm{EV} ; H$ dac2, $\mathrm{F}_{(1,22)}=5.034$ and $\mathrm{p}=0.0353$ for GC main effect, $\mathrm{F}_{(1,22)}=0.2970$ and $\mathrm{p}=0.5913$ for $L$-EV main effect, and $\mathrm{F}_{(1,22)}=3.793$ and $\mathrm{p}=0.0643$ for $\mathrm{GC} \times L$-EV; Creb1, $\mathrm{F}_{(1,26)}=0.0513$ and $\mathrm{p}=0.8227$ for GC main effect, $\mathrm{F}_{(1,26)}=4.846$ and $\mathrm{p}=0.0368$ for $L$-EV main effect, and $\mathrm{F}_{(1,26)}=0.0056$ and $\mathrm{p}=0.9412$ for $\mathrm{GC} \times L$-EV). (D, E) Expression levels of Sirt1 (D), tBdnf, Bdnf1, Bdnf4, and Crebl(E) in HT22 cells treated with siRNA-CON (50 pmol), siRNA-Sirt1 (50 pmol), L-EV (20 $\mu \mathrm{g} / \mathrm{ml})$ or siRNASirt $1+L$-EV for $24 \mathrm{~h}$ ( $\mathrm{n}=5 \sim 10$ per group). Two-way ANOVA followed by Bonferroni post hoc test (Sirt1, $\mathrm{F}_{(1,23)}=22.48$ and $\mathrm{p}<0.0001$ for siSirt1 main effect, $\mathrm{F}_{(1,23)}=0.5684$ and $\mathrm{p}=0.4586$ for $L$-EV main effect, and $\mathrm{F}_{(1,23)}=0.3164$ and $\mathrm{p}=0.5792$ for siSirt $1 \times L-E V ; H d a c 2, \mathrm{~F}_{(1,28)}=1.194$ and $\mathrm{p}=0.2839$ for siSirt 1 main effect, $\mathrm{F}_{(1,28)}=0.4969$ and $\mathrm{p}=0.4867$ for $L$-EV main effect, and $\mathrm{F}_{(1,28)}=2.108$ and $\mathrm{p}=0.1576$ for siSirt $1 \times L$-EV; $C r e b 1, \mathrm{~F}_{(1,19)}=47.84$ and $\mathrm{p}<0.0001$ for siSirt 1 main effect, $\mathrm{F}_{(1,19)}=0.0141$ and $\mathrm{p}=0.9069$ for $L$-EV main effect, and $\mathrm{F}_{(1,19)}=0.1306$ and $\mathrm{p}=0.7218$ for siSirt $1 \times L$-EV; $\mathrm{t} B d n f, \mathrm{~F}_{(1,24)}=3.681$ and $\mathrm{p}=0.0670$ for siSirt 1 main effect, $\mathrm{F}_{(1,24)}=1.632$ and $\mathrm{p}=0.2137$ for $L$-EV main effect, and $\mathrm{F}_{(1,24)}=1.446$ and $\mathrm{p}=0.2409$ for siSirt $1 \times L$-EV; $B d n f 1, \mathrm{~F}_{(1,21)}=5.607$ and $\mathrm{p}=0.0276$ for siSirtl main effect, $\mathrm{F}_{(1,21)}=0.7048$ and $\mathrm{p}=0.4106$ for $L$-EV main effect, and $\mathrm{F}_{(1,21)}=0.7991$ and $\mathrm{p}=0.3815$ for siSirt $1 \times L$-EV; $B d n f 4, \mathrm{~F}_{(1,23)}=25.64$ and $\mathrm{p}<0.0001$ for siSirtl main effect, $\mathrm{F}_{(1,23)}=0.3326$ and $\mathrm{p}=0.5697$ for $L$-EV main effect, and $\mathrm{F}_{(1,23)}=0.1315$ and $\mathrm{p}=0.7202$ for siSirt $1 \times L$-EV). GC, glucocorticoid; veh, vehicle. Data are presented as mean \pm SEM. ${ }^{*} \mathrm{p}<0.05 ;{ }^{* *} \mathrm{p}<0.01$. 
A

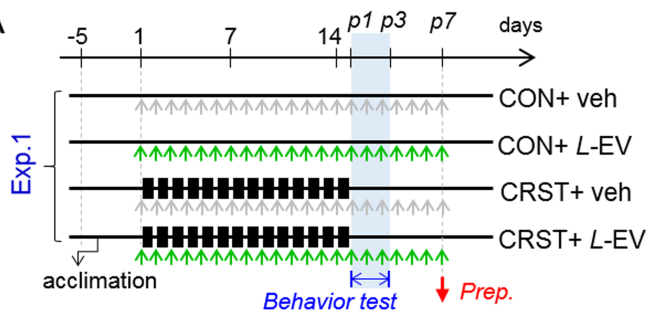

【2h RST $\uparrow$ vehicle injection $\uparrow L$-EV injection

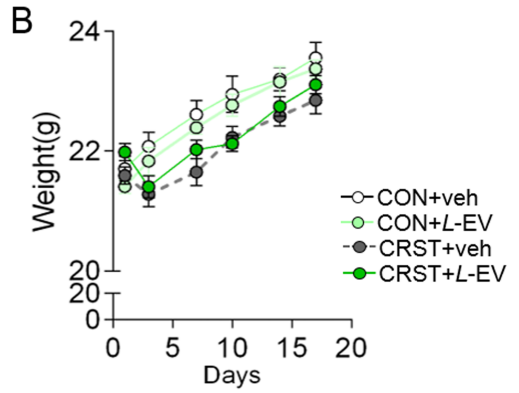

D $\square$ CON+veh aCRST+veh $\square \mathrm{CON}+L-\mathrm{EV} \quad \square \mathrm{CRST}+L-\mathrm{EV}$ $\begin{array}{llll}L-E V & + & + & +\end{array}$ proBDNF $=-\cdots+32 \mathrm{kDa}$ ß-actin $----442 \mathrm{kDa}$
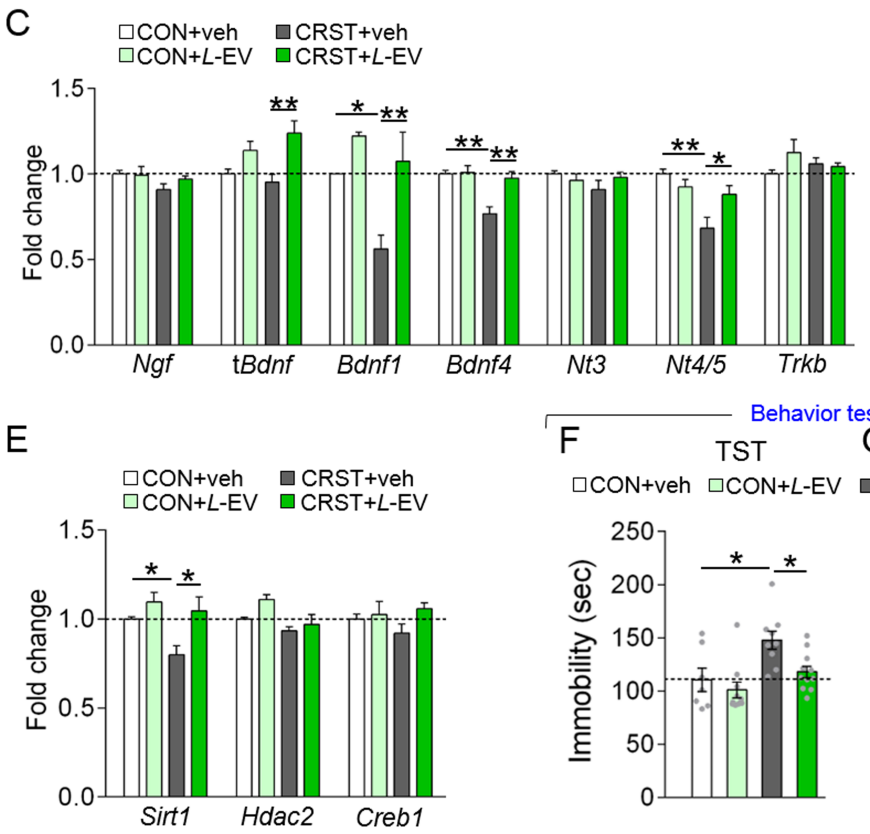

st (Exp.1) $\square \mathrm{CON}+\mathrm{veh} \square \mathrm{CON}+L-E V \quad \square \mathrm{CRST}+\mathrm{veh} \square \mathrm{CRST}+L-E V$
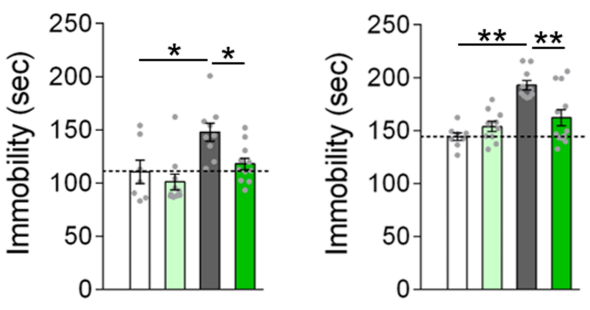

Fig. 2. $L$-EV treatment during the stress-treatment period blocked the stress-induced decrease in the expression of neurotrophic factors in the hippocampus and inhibited stress-induced depressive-like behaviors. (A) Experimental design (Exp. 1). Mice were treated with restraint for 2-h daily for 14 days $(2 \mathrm{~h} \times 14 \mathrm{~d}$ RST). Saline or $L$-EV $(0.1 \mu \mathrm{g} / \mathrm{kg})$ were i.p. injected $30 \mathrm{~min}$ before restraint treatment each day. Behavioral tests were performed on post-stress days 1-3 (p1 p3) and mice were sacrificed on post-stress day 7 ( $p 7)$. Control mice injected with saline (CON+veh), mice treated with $L$-EV $(\mathrm{CON}+L-\mathrm{EV})$, mice treated with repeated restraint and injected with saline (CRST+veh), and mice treated with repeated restraint and injected with $L$-EV (CRST $+L$-EV) were prepared. (B) Body weight (g) changes of $\mathrm{CON}+\mathrm{veh}, \mathrm{CON}+L-\mathrm{EV}, \mathrm{CRST}+\mathrm{veh}$, and CRST $+L-\mathrm{EV}$ ( $\mathrm{n}=8 \sim 12$ animals per group). (C) Expression levels of $N g f, \mathrm{t} B d n f, B d n f 1, B d n f 4, N t 3, N t 4 / 5$, and Trkb in the hippocampus of CON+veh, CON $+L$-EV, CRST+veh, and CRST $+L$-EV ( $\mathrm{n}=6$ animals and 4 8 PCR repeats per group). Two-way ANOVA followed by Bonferroni post hoc test $\left(\mathrm{Ngf}, \mathrm{F}_{(1,28)}=2.900\right.$ and $\mathrm{p}=0.0997$ for CRST main effect, $\mathrm{F}_{(1,28)}=0.6187$ and $\mathrm{p}=0.4381$ for $L$-EV main effect, and $\mathrm{F}_{(1,28)}=1.024$ and $\mathrm{p}=0.3202$ for $\mathrm{CRST} \times L$-EV; $\mathrm{t} B d n f, \mathrm{~F}_{(1,25)}=0.2452$ and $\mathrm{p}=0.6248$ for $\mathrm{CRST}$ main effect, $\mathrm{F}_{(1,25)}=15.43$ and $\mathrm{p}=0.0006$ for $L$-EV main effect, and $\mathrm{F}_{(1,25)}=1.932$ and $\mathrm{p}=0.1768$ for CRST $\times L$-EV; $B d n f 1, \mathrm{~F}_{(1,12)}=9.542$ and $\mathrm{p}=0.0094$ for CRST main effect, $\mathrm{F}_{(1,12)}=15.01$ and $\mathrm{p}=0.0022$ for $L$-EV main effect, and $\mathrm{F}_{(1,12)}=2.324$ and $\mathrm{p}=0.1533$ for $\mathrm{CRST} \times L$-EV; $B d n f 4, \mathrm{~F}_{(1,12)}=13.95$ and $\mathrm{p}=0.0028$ for $\mathrm{CRST}$ main effect, $\mathrm{F}_{(1,12)}=9.418$ and $\mathrm{p}=0.0097$ for $L$-EV main effect, and $\mathrm{F}_{(1.12)}=8.003$ and $\mathrm{p}=0.0152$ for CRST $\times L-E V ; N t 3, \mathrm{~F}_{(1,28)}=0.9424$ and $\mathrm{p}=0.3400$ for $\mathrm{CRST}$ main effect, $\mathrm{F}_{(1,28)}=0.1996$ and $\mathrm{p}=0.6585$ for $L$-EV main effect, and $\mathrm{F}_{(1,28)}=1.974$ and $\mathrm{p}=0.1710$ for $\mathrm{CRST} \times L$-EV; $N t 4 / 5, \mathrm{~F}_{(1,24)}=14.45$ and $\mathrm{p}=0.0009$ for $\mathrm{CRST}$ main effect, $\mathrm{F}_{(1,24)}=1.654$ and $\mathrm{p}=0.2106$ for $L$-EV main effect, and $\mathrm{F}_{(1,24)}=8.419$ and $\mathrm{p}=0.0078$ for $\mathrm{CRST} \times L$-EV; Trkb, $\mathrm{F}_{(1,14)}=0.0650$ and $\mathrm{p}=0.8025$ for $\mathrm{CRST}$ main effect, $\mathrm{F}_{(1,14)}=1.768$ and $\mathrm{p}=0.2049$ for $L$-EV main effect, and $\mathrm{F}_{(1,14)}=2.969$ and $\mathrm{p}=0.1069$ for $\mathrm{CRST} \times L$-EV). (D) Western blot data showing the expression level of proBDNF in the hippocampus of $\mathrm{CON}+\mathrm{veh}, \mathrm{CON}+L-\mathrm{EV}$, CRST + veh, and $\mathrm{CRST}+L-\mathrm{EV}$ ( $\mathrm{n}=6$ animals and $4 \mathrm{WB}$ repeats per group). Twoway ANOVA followed by Bonferroni post hoc test $\left(\mathrm{F}_{(1,12)}=12.29\right.$ and $\mathrm{p}=0.0043$ for CRST main effect, $\mathrm{F}_{(1,12)}=1.697$ and $\mathrm{p}=0.2172 \mathrm{for} L$-EV main effect, and $\mathrm{F}_{(1,12)}=8.952$ and $\mathrm{p}=0.0112$ for CRST $\left.\times L-E V\right)$. (E) Expression levels of Sirt1, Hdac2, and Creb1 in the hippocampus of CON+veh, CON $+L-E V, C R S T+v e h$, and CRST $+L-E V$ ( $\mathrm{n}=6$ animals and 6-10 PCR repeats per group). Two-way ANOVA followed by Bonferroni post hoc test (Sirt1, $\mathrm{F}_{(1,23)}=6.483$ and $\mathrm{p}=0.0181$ for CRST main effect, $\mathrm{F}_{(1,23)}=12.17$ and $\mathrm{p}=0.0020$ for $L$-EV main effect, and $\mathrm{F}_{(1,23)}=2.365$ and $\mathrm{p}=0.1377$ for $\mathrm{CRST} \times L$-EV; Hdac2, $\mathrm{F}_{(1,25)}=10.31$ and $\mathrm{p}=0.0036$ for CRST main effect, $\mathrm{F}_{(1,25)}=5.110$ and $\mathrm{p}=0.0327$ for $L$-EV main effect, and $\mathrm{F}_{(1,25)}=1.340$ and $\mathrm{p}=0.2280$ for $C R S T \times L-E V ; C r e b 1, \mathrm{~F}_{(1,22)}=0.2456$ and $\mathrm{p}=0.6251$ for CRST main effect, $\mathrm{F}_{(1,22)}=2.829$ and $\mathrm{p}=0.1067$ for $L$-EV main effect, and $\mathrm{F}_{(1,22)}=1.358$ and $\mathrm{p}=0.2564$ for $\mathrm{CRST} \times L$-EV). (F, G) Immobility time in the tail suspension test (TST; F) and forced swim test (FST; G) of CON+veh, CON $+L-E V$, CRST+veh, and CRST $+L$-EV ( $\mathrm{n}=7 \sim 12$ animals per group). Two-way ANOVA followed by Bonferroni post hoc test (TST, $\mathrm{F}_{(1,33)}=11.90$ and $\mathrm{p}=0.0016$ for CRST main effect, $\mathrm{F}_{(1,33)}=6.235$ and $\mathrm{p}=0.0177$ for $L$-EV main effect, and $\mathrm{F}_{(1,33)}=1.665$ and $\mathrm{p}=0.2059$ for $\mathrm{CRST} \times L$-EV; FST, $\mathrm{F}_{(1,36)}=23.84$ and $\mathrm{p}<0.0001$ for CRST main effect, $\mathrm{F}_{(1,36)}=3.265$ and $\mathrm{p}=0.0792$ for $L$-EV main effect, and $\mathrm{F}_{(1,36)}=12.17$ and $\mathrm{p}=0.0013$ for $\mathrm{CRST} \times L$-EV). Data are presented as mean \pm SEM. ${ }^{*} \mathrm{p}<0.05 ;{ }^{* *} \mathrm{p}<0.01$. 
ment $(20 \mu \mathrm{g} / \mathrm{ml})$ reversed GC-induced reduced expression of $\mathrm{t} B d n f, B d n f 1, B d n f 4$, and $N g f$ (Fig. 1A). Western blot analysis confirmed that $L$-EV treatment blocked GC-induced reduced expression of proBDNF (Fig. 1B).

\section{L-EV treatment in HT22 cells increased BDNF expression via Sirt1}

BDNF expression is regulated by transcription and/or epigenetic factors, including cAMP response element (CRE) binding protein (CREB1) [46], histone acetyltransferase 2 (HDAC2) [47], and Sirtuin 1 (Sirt1) [48]. HDAC2 negatively regulates BDNF expression in stress-induced depression models [47], whereas CREB1 and Sirt1 enhance BDNF expression [47-49].

GC treatment in HT22 cells decreased Sirt1 expression, but not significantly $\mathrm{Creb} 1$ and $H d a c 2$, whereas $L$-EV treatment increased the GC-induced reduced expression of Sirt1, but produced no significant change in Creb1 and Hdac2 expression (Fig. 1C). The siRNA-mediated knockdown of Sirt1 in HT22 cells reduced the expression of $\mathrm{t} B d n f, B d n f 1, B d n f 4$, and $C r e b 1$, and under the suppression of Sirt1, $L$-EV treatment did not increase the expression of Bdnf4 and Creb1 (Fig. 1D and 1E). These results suggest that Sirt1 plays a role in $L$-EV-induced upregulation of $B d n f 4$ and Creb1.

\section{L-EV treatment in mice during the stress treatment phase blocked stress-induced depressive-like behaviors}

Next, we examined whether $L$-EV treatment in mice affected BDNF expression in the brain and stress-induced depressive-like behaviors. Mice treated with restraint for 2-h daily for 14 days (CRST; 2h x 14d RST) exhibited depressive-like behaviors [37], and had reduced expression of BDNF in the hippocampus [50]. Consistent with these reports, mice treated with CRST had reduced expression of $B d n f 1, B d n f 4$, and Nt4/5 in the hippocampus compared to that of control mice (Fig. 2A and 2C). Conversely, mice treated with $L$-EVs prior to each restraint (RST $+L$-EV; Fig. 2A) had increased expression of $B d n f 1, B d n f 4$, and Nt4/5 compared to that of CRST mice (Fig. 2A and 2C). Western blot analysis also indicated that proBDNF levels were reduced after CRST treatment, whereas $L$-EV injection at each stress session blocked the stress-induced decreased expression of proBDNF (Fig. 2D).

The body weight of mice decreased during restraint treatment, but was not affected by $L$-EV treatment (Fig. 2B). Mice treated with CRST tended to have reduced expression of Sirt 1 in the hippocampus, whereas $L$-EV treatment during the stress session blocked the stress-induced reduced expression of SirtI (Fig. 2E). In contrast, there was no change in $\mathrm{Hdac} 2$ and $\mathrm{Creb} 1$ expression. Behavioral tests indicated that mice treated with CRST exhibited increased immobility in the TST and FST (Fig. 2F and 2G). In contrast, $L$-EV treatment prior to each restraint (Fig. 2A) blocked stress-induced increased immobility in the TST and FST (Fig. 2F and $2 \mathrm{G}$ ).

These results suggest that $L$-EV treatment in mice during the stress induction phase blocks stress-induced reduced expression of BDNF in the hippocampus and stress-induced depressive-like behaviors.

\section{L-EV treatment in CRST-treated mice rescued stress-in- duced depressive-like behaviors}

Next, we examined whether $L$-EV treatment in the post-stress phase produced antidepressant-like effects. Mice treated with restraint for 2-h daily for 14 days had reduced expression of $\mathrm{t} B d n f$, $B d n f 4$, and $N t 3$, and tended to have reduced expression of $B d n f 1$ and $N t 4 / 5$ in the hippocampus compared to that of control mice on post-stress day 35 (p35) (Fig. 3A and 3C). Thus, stress-induced changes in the expression of these neurotrophic factors in the hippocampus were long-lasting. On the contrary, $L$-EV treatment in CRST-treated mice blocked the reduced expression of $\mathrm{t} B d n f$, $B d n f 1, B d n f 4$, and Nt4/5 in the hippocampus (Fig. $3 \mathrm{~A}$ and $3 \mathrm{C}$ ). CRST-induced body weight changes occurred, whereas post-stress treatment with $L$-EVs or IMI produced no significant effect on body weight (Fig. 3B). Western blot analysis indicated that mice treated with CRST had reduced expression of proBDNF in the hippocampus, whereas post-stress treatment with $L$-EVs in CRSTtreated mice suppressed stress-induced reduced expression of proBDNF and BDNF (Fig. 3D).

Mice treated with CRST showed reduced social interaction in the sociability test (Fig. 3E and 3F) and increased immobility time in the TST and FST (Fig. 3G and 3H). In contrast, post-stress treatment with $L$-EVs in CRST-treated mice reversed decreased sociability in the sociability test, and reduced stress-induced increased immobility in the TST and FST (Fig. 3E H). These data indicated that antidepressant-like effects of $L$-EVs are comparable to those of imipramine (Fig. 3E H).

Next, we examined whether antidepressant-like effects of $L$-EVs were sustained long after the termination of $L$-EV treatment (Fig. $3 A$ ). When reassessed on post-stress days 29-30, mice treated with CRST exhibited depressive-like behaviors in the sociability test (Fig. 3I and 3J) and in the TST and FST (Fig. 3K and 3L), whereas mice treated with CRST followed by $L$-EVs in the post-stress phase showed increased sociability and reduced immobility in the TST and FST, which were also comparable to those of mice treated with imipramine (Fig. 3I L). These results suggest that $L$-EVs produce antidepressant-like effects in mice with stress-induced depression, and $L$-EV-induced antidepressant-like effects are stably 


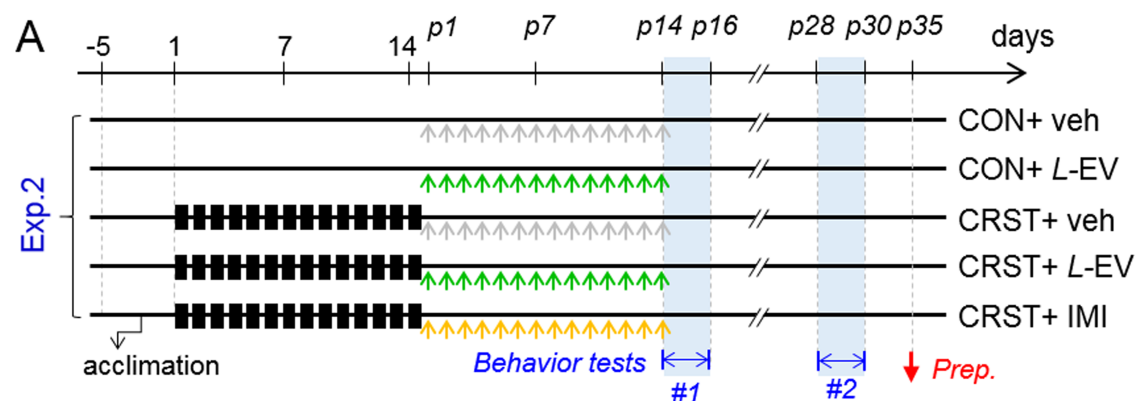

【2h RST $\uparrow$ vehicle injection $\uparrow L$-EV injection $\uparrow$ Imipramine injection

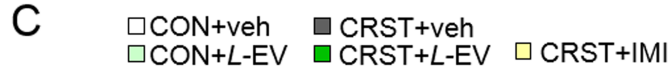

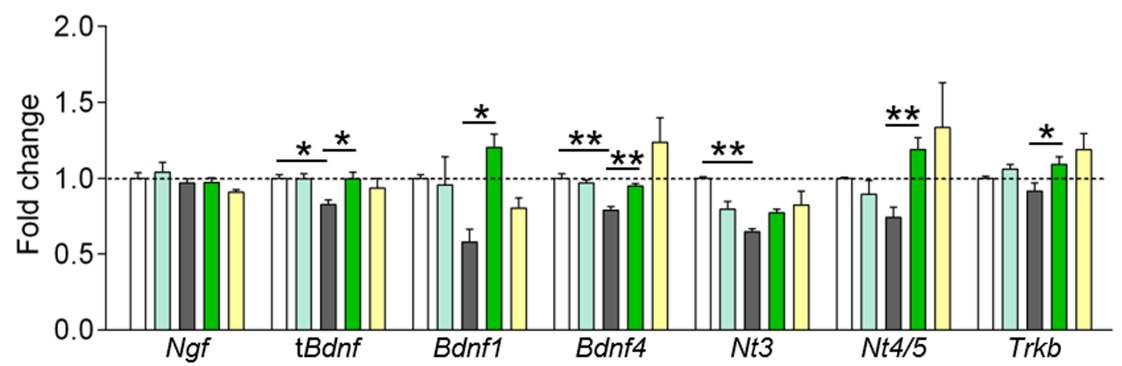

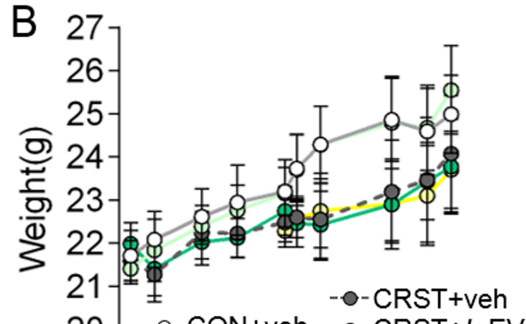

$20 \perp-C O N+v e h-0-C R S T+L-E V$ $20 \mathrm{O}-\mathrm{CON}+L-E V-C R S T+\mid \mathrm{Ml}$ $\begin{array}{lllllll}0 & 5 & 10 & 15 & 20 & 25 & 30\end{array}$ Days

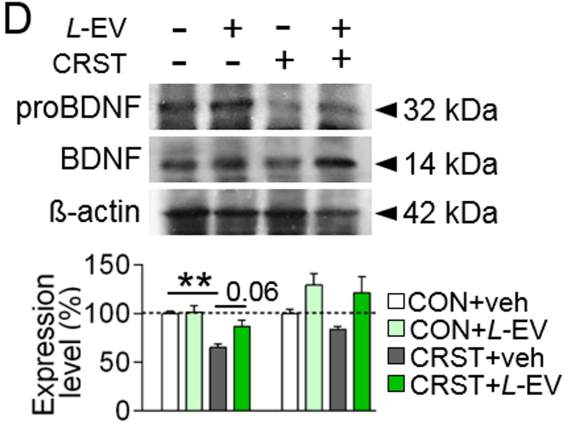

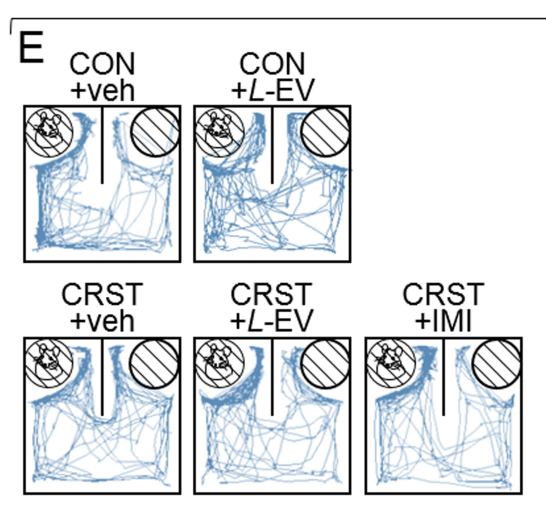

$\mathrm{F} \quad$ Sociability
$\square \mathrm{CON+veh} \quad \square \mathrm{CRST}+\mathrm{veh}$
$\square \mathrm{CON}+L-\mathrm{EV} \quad \square \mathrm{CRST}+L-\mathrm{EV}$
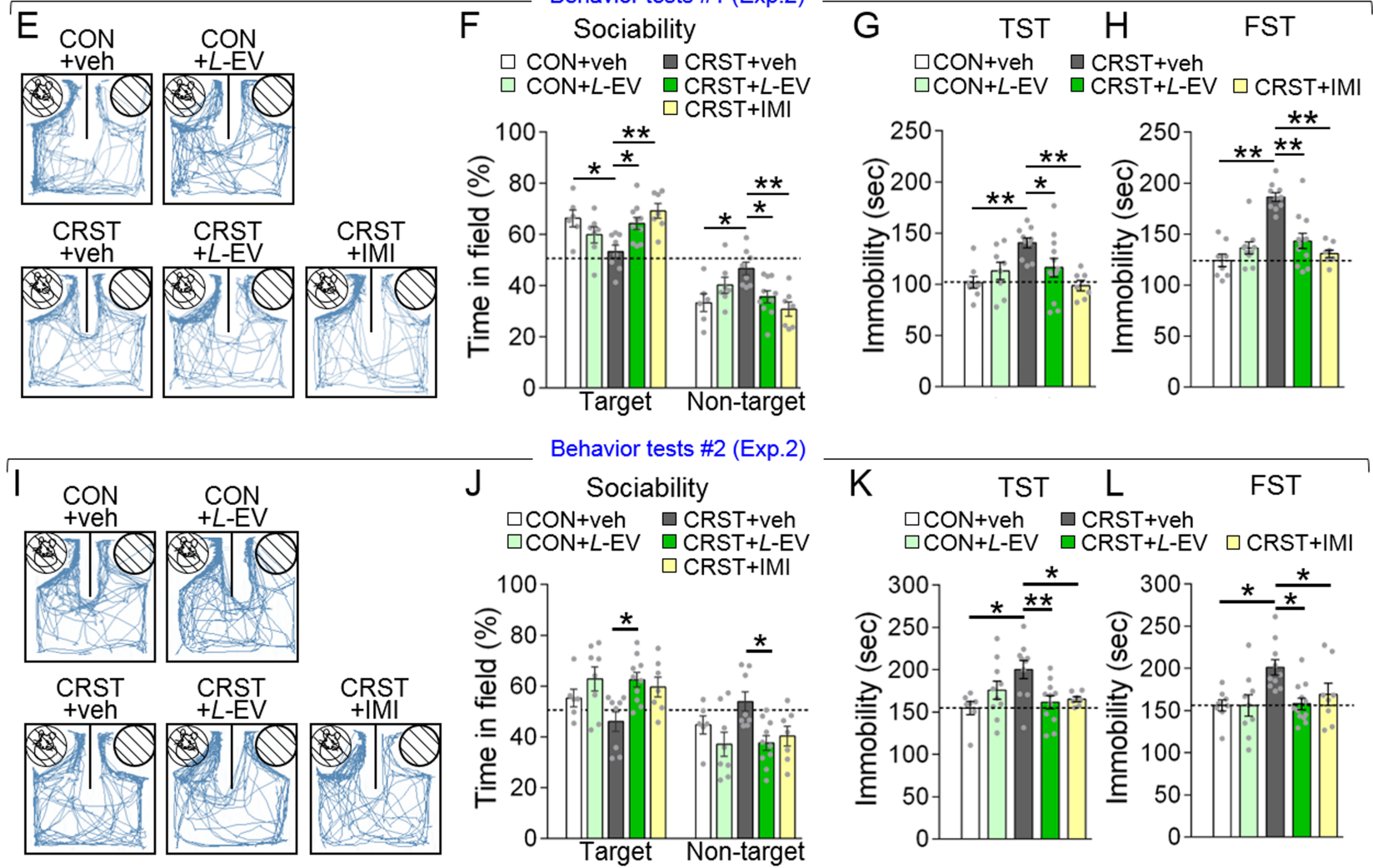

Fig. 3. $L$-EV treatment in CRST-treated mice reversed stress-induced decreased expression of BDNF in the hippocampus and rescued stress-induced depressive-like behaviors. (A) Experimental design (Exp.2). Mice exposed to CRST ( $2 \mathrm{~h} \times 14 \mathrm{~d} \mathrm{RST}$ ) were treated with saline, imipramine (20 mg/kg), and $L$-EV $(0.1 \mu \mathrm{g} / \mathrm{kg}$ for days $1 \sim 5 ; 0.18 \mu \mathrm{g} / \mathrm{kg}$ for days $6 \sim 7 ; 0.27 \mu \mathrm{g} / \mathrm{kg}$ for day 8 and thereafter). Behavior tests were performed on post-stress days $14 \sim 16$ ( 1 14 p 16; behavior tests, \#1) and post-stress days 28 30 (p28 p30; behavior tests, \#2). Mice were sacrificed on post-stress day 35 (p35). Control mice injected with saline $(\mathrm{CON}+\mathrm{veh})$, mice treated with $L-\mathrm{EV}(\mathrm{CON}+L-\mathrm{EV})$, mice treated with repeated restraint and injected with saline $(\mathrm{CRST}+\mathrm{veh})$, 
Fig. 3. (Continued) and mice treated with repeated restraint and injected with $L$-EV (CRST $+L-E V)$ and mice treated with repeated restraint and injected with imipramine (CRST+IMI) were prepared. (B) Body weight changes of CON+veh, $C O N+L-E V$, CRST + veh, $C R S T+L-E V$, and CRST $+I M I$ ( $\mathrm{n}=8 \sim 12$ animals per group). (C) Expression levels of $N g f, \mathrm{t} B d n f, B d n f 1, B d n f 4, N t 3, N t 4 / 5$, and Trkb in the hippocampus of CON+veh, CON $+L$-EV, CRST+veh, $C R S T+L-E V$, and CRST $+\mathrm{IMI}(\mathrm{n}=6 \sim 8$ animals and $4 \sim 6$ PCR repeats per group). For the comparison of CON $+v e h, C O N+L-E V, C R S T+v e h$, and CRST $+L$-EV groups, two-way ANOVA followed by Bonferroni post hoc test was used $\left(\mathrm{Ngf}, \mathrm{F}_{(1,14)}=1.549\right.$ and $\mathrm{p}=0.2337$ for CRST main effect; $\mathrm{F}_{(1,14)}=0.3197$ and $\mathrm{p}=0.5808$ for $L$-EV main effect; $\mathrm{F}_{(1,14)}=0.1826$ and $\mathrm{p}=0.6757$ for $\mathrm{CRST} \times L$-EV; $\mathrm{t} B d n f, \mathrm{~F}_{(1,14)}=4.871$ and $\mathrm{p}=0.0445$ for CRST main effect; $\mathrm{F}_{(1,14)}=4.274$ and $\mathrm{p}=0.0577$ for $L$-EV main effect; $\mathrm{F}_{(1,14)}=4.752$ and $\mathrm{p}=0.0468$ for CRST $\times L$-EV; $B d n f 1, \mathrm{~F}_{(1,12)}=0.5907$ and $\mathrm{p}=0.4570$ for CRST main effect; $\mathrm{F}_{(1,12)}=6.682$ and $\mathrm{p}=0.0239$ for $L$-EV main effect; $\mathrm{F}_{(1,12)}=8.992$ and $\mathrm{p}=0.0111$ for $\mathrm{CRST} \times L$-EV; $B d n f 4, \mathrm{~F}_{(1,13)}=25.35$ and $\mathrm{p}=0.0002$ for CRST main effect; $\mathrm{F}_{(1,13)}=7.794$ and $\mathrm{p}=0.0153$ for $L$-EV main effect; $\mathrm{F}_{(1,13)}=17.60$ and $\mathrm{p}=0.0010$ for CRST $\times L$-EV; $N t 3, \mathrm{~F}_{(1,14)}=43.45$ and $\mathrm{p}<0.0001$ for CRST main effect; $\mathrm{F}_{(1,14)}=3.274$ and $\mathrm{p}=0.0919$ for $L$-EV main effect; $\mathrm{F}_{(1,14)}=22.21$ and $\mathrm{p}=0.0003$ for CRST $\times L$-EV; $N t 4 / 5, \mathrm{~F}_{(1,11)}=0.0645$ and $\mathrm{p}=0.8042$ for CRST main effect; $\mathrm{F}_{(1,11)}=6.108$ and $\mathrm{p}=0.0310$ for $L$-EV main effect; $\mathrm{F}_{(1,11)}=15.76$ and $\mathrm{p}=0.0022$ for CRST $\times L$-EV; Trkb, $\mathrm{F}_{(1,14)}=0.3743$ and $\mathrm{p}=0.5505$ for CRST main effect; $\mathrm{F}_{(1,14)}=7.106$ and $\mathrm{p}=0.0185$ for $L$-EV main effect; $\mathrm{F}_{(1,14)}=1.669$ and $\mathrm{p}=0.2173$ for $\left.\mathrm{CRST} \times L-\mathrm{EV}\right)$. For the comparison of CON+veh, CRST $+\mathrm{veh}, \mathrm{CRST}+L-\mathrm{EV}$, and CRST+IMI groups, one-way ANOVA followed by Newman-Keuls post hoc test was used $\left(\mathrm{Ngf}, \mathrm{F}_{(3,14)}=1.495\right.$ and $\mathrm{p}=0.2591 ; \mathrm{t} B d n f, \mathrm{~F}_{(3,14)}=2.938$ and $\mathrm{p}=0.0699 ; B d n f 1, \mathrm{~F}_{(3,11)}=14.81$ and $\mathrm{p}=0.0004 ; B d n f 4, \mathrm{~F}_{(3,13)}=5.176$ and $\mathrm{p}=0.0143 ; N t 3, \mathrm{~F}_{(3,12)}=9.203$ and $\mathrm{p}=0.0020 ; N t 4 / 5, \mathrm{~F}_{(3,11)}=2.170$ and $\mathrm{p}=0.1493 ;$ Trkb, $\mathrm{F}_{(3,14)}=3.280$ and $\left.\mathrm{p}=0.0527\right)$. (D) Western blot analysis of proBDNF and BDNF expression in the hippocampus of CON+veh, CON $+L-E V, C R S T+v e h$, and CRST $+L$-EV ( $\mathrm{n}=8$ animals and $3 \sim 5 \mathrm{WB}$ repeats per group). Two-way ANOVA followed by Bonferroni post hoc test (proBDNF, $\mathrm{F}_{(1,16)}=22.62$ and $\mathrm{p}=0.0002$ for CRST main effect, $\mathrm{F}_{(1,16)}=4.830$ and $\mathrm{p}=0.0430$ for $L$-EV main effect, and $\mathrm{F}_{(1,16)}=3.681$ and $\mathrm{p}=0.0731 \mathrm{for} C \mathrm{CRST} \times L$-EV; $\mathrm{BDNF}, \mathrm{F}_{(1,8)}=1.329$ and $\mathrm{p}=0.2823$ for CRST main effect, $\mathrm{F}_{(1,8)}=10.25$ and $\mathrm{p}=0.0126$ for $L$-EV main effect, and $\mathrm{F}_{(1,8)}=0.1521$ and $\mathrm{p}=0.7067$ for $\mathrm{CRST} \times L$-EV). (E H) Behavior tests (\#1) on post-stress days $14 \sim 16$. Representative tracking of mice placed in the sociability test (E). The percent time (\%) spent in the target or nontarget fields (F), and immobility time in the TST $(\mathrm{G})$ and FST $(\mathrm{H})$ of CON+veh, CON $+L-E V$, CRST+veh, CRST $+L$-EV, and CRST $+\mathrm{IMI}(\mathrm{n}=6 \sim 12$ animals per group). Two-way ANOVA followed by Bonferroni post hoc test was used for the comparison of CON+veh, CON $+L-E V, C R S T+v e h, C R S T+L-E V$ (target field in the sociability test, $\mathrm{F}_{(1,27)}=2.243$ and $\mathrm{p}=0.1458$ for CRST main effect, $\mathrm{F}_{(1,27)}=0.6705$ and $\mathrm{p}=0.4200$ for $L$-EV main effect, and $\mathrm{F}_{(1,27)}=9.550$ and $\mathrm{p}=0.0046$ for CRST $\times L$-EV; non-target field in the sociability test, $\mathrm{F}_{(1,27)}=2.420$ and $\mathrm{p}=0.1315$ for CRST main effect, $\mathrm{F}_{(1,27)}=0.5370$ and $\mathrm{p}=0.4700$ for $L$-EV main effect, and $\mathrm{F}_{(1,27)}=9.869$ and $\mathrm{p}=0.0041$ for CRST $\times L$-EV; TST, $\mathrm{F}_{(1,34)}=7.324$ and $\mathrm{p}=0.0 .106$ for CRST main effect, $\mathrm{F}_{(1,34)}=0.6786$ and $\mathrm{p}=0.4158$ for $L$-EV main effect, and $\mathrm{F}_{(1,34)}=5.308$ and $\mathrm{p}=0.0275$ for CRST $\times L$-EV; FST, $\mathrm{F}_{(1,35)}=29.00$ and $\mathrm{p}<0.0001$ for CRST main effect, $\mathrm{F}_{(1,35)}=5.846$ and $\mathrm{p}=0.0210$ for $L$-EV main effect, and $\mathrm{F}_{(1,35)}=18.19$ and $\mathrm{p}=0.0001$ for $\mathrm{CRST} \times L$-EV). One-way ANOVA followed by Neuman-Keuls post hoc test was for the comparison of CON+veh, CRST+veh, CRST $+L-\mathrm{EV}$ and CRST+IMI (target field in the sociability test, $\mathrm{F}_{(3,27)}=6.470$ and $\mathrm{p}=0.0019$; non-target field in the sociability test, $\mathrm{F}_{(3,27)}=6.435$ and $\mathrm{p}=0.0020$; TST, $\mathrm{F}_{(3,33)}=6.772$ and $\mathrm{p}=0.001 ; \mathrm{FST}, \mathrm{F}_{(3,34)}=21.57$ and $\mathrm{p}<0.0001$ ). (I L) Behavior tests (\#2) on post-stress days $28 \sim 30$. Representative tracking of mice placed in the sociability test (I). The percent time (\%) spent in the target or non-target fields (J), and immobility time in the TST (K) and FST (L) of CON+veh, CON $+L$-EV, CRST+veh, CRST+L-EV, and CRST+IMI ( $\mathrm{n}=6 \sim 12$ animals per group). Two-way ANOVA followed by Bonferroni post hoc test was used for the comparison of CON+veh, CON $+L-E V, C R S T+v e h, C R S T+L-E V\left(\operatorname{target}\right.$ field in the sociability test, $\mathrm{F}_{(1,28)}=1.580$ and $\mathrm{p}=0.2192$ for CRST main effect, $\mathrm{F}_{(1,28)}=9.744$ and $\mathrm{p}=0.0041$ for $L$-EV main effect, and $\mathrm{F}_{(1,28)}=1.332$ and $\mathrm{p}=0.2582$ for CRST $\times L$-EV; non-target field in the sociability test, $\mathrm{F}_{(1,28)}=1.557$ and $\mathrm{p}=0.2224$ for CRST main effect, $\mathrm{F}_{(1,28)}=9.706$ and $\mathrm{p}=0.0042$ for $L$-EV main effect, and $\mathrm{F}_{(1,28)}=1.304$ and $\mathrm{p}=0.2632$ for CRST $\times L$-EV; TST, $\mathrm{F}_{(1,36)}=2.902$ and $\mathrm{p}=0.0971$ for CRST main effect, $\mathrm{F}_{(1,36)}=0.6042$ and $\mathrm{p}=0.4421$ for $L$-EV main effect, and $\mathrm{F}_{(1,36)}=6.737$ and $\mathrm{p}=0.0136$ for CRST $\times L$-EV; FST, $\mathrm{F}_{(1,35)}=6.714$ and $\mathrm{p}=0.0139$ for CRST main effect, $\mathrm{F}_{(1,35)}=5.713$ and $\mathrm{p}=0.0224$ for $L$-EV main effect, and $\mathrm{F}_{(1,35)}=5.783$ and $\mathrm{p}=0.0216$ for CRST $\times L-E V)$. One-way ANOVA followed by Neuman-Keuls post hoc test was for the comparison of CON+veh, CRST+veh, CRST $+L-E V$ and CRST+IMI (target field in the sociability test, $\mathrm{F}_{(3,27)}=4.567$ and $\mathrm{p}=0.0103$; non-target field in sociability test, $\mathrm{F}_{(3,27)}=4.535$ and $\mathrm{p}=0.0106$; TST, $\mathrm{F}_{(3,31)}=6.029$ and $\mathrm{p}=0.0023 ; \mathrm{FST}, \mathrm{F}_{(3,34)}=5.762$ and $\left.\mathrm{p}=0.0027\right)$. Data are presented as mean $\pm \mathrm{SEM} .{ }^{*} \mathrm{p}<0.05 ;{ }^{* *} \mathrm{p}<0.01$.

maintained.

\section{DISCUSSION}

\section{Lactobacillus-derived EVs increased BDNF expression in the hippocampus and rescued depressive-like behaviors}

In the present study, we demonstrated that $L$-EV treatment in mice showing stress-induced depression increased BDNF expression in the hippocampus and produced antidepressant-like effects (Fig. 2 and 3). The results of antidepressant-like effects of $L$-EVs are consistent with the previous reports showing beneficial effects of Lactobacillus spp. on various mental disorders. For example, the supplement of Lactobacillus rhamnosus reduced stress-induced increase of corticosterone and anxiety- and depression-related behavior [8] and decreased stress-induced anxiety-like behavior and deficits in social interaction [51]. Treatment of Lactobacil- lus helveticus NS8 in hyperammonemia rats attenuated the level of inflammatory markers, restored cognitive function and improved anxiety-like behavior [52]. Furthermore, administration of Lactobacillus helveticus NS8 produced antidepressant effects in rats subjected to chronic restraint stress [10]. Oral ingestion of Lactobacillus paracasei in senescence accelerated mouse prone 8 (SAMP8) mice delayed age-related cognitive decline, possibly by preventing oxidation and inflammation [53]. Lactobacillus plantarum C29 treatment increased hippocampal BDNF and p-CREB expression and protected scopolamine-induced memory deficit in the Y-maze and Morris water maze tests [54]. Furthermore, supplementation of Lactobacillus plantarum prevented stress-induced depressive-like behaviors in mice [35], and attenuated anxiety-related behavior in zebrafish [34]. Thus, given that supplementation of Lactobacillus spp. produces beneficial effects on cognitive and emotional dysfunction in various experimental conditions, it is 
important to note that $L$-EVs are sufficient to produce antidepressant effects. The antidepressant-like effects of $L$-EVs on behaviors were comparable to those of IMI (Fig. 3), whereas $L$-EV effects on the expression of neurotropic factors and TrkB were only partially overlapped with those of IMI, raising the possibility that $L$-EVs might exert antidepressant-like effects in a way slightly different from that of IMI, and therefore $L$-EVs could provide something that IMI does not afford.

The results of EVs-induced increase of BDNF and other genes in HT22 cells (Fig. 1) indicate that EVs can induce genomic responses by directly acting on cells. Considering that intraperitoneally (i.p.) injected $L$-EVs in mice induced genomic responses in the brain that were similar to those observed in HT22 cells (Fig. $1 \sim 3$ ), it is possible that i.p.-injected EVs directly acted on the brain. It is well known that i.p.-injected drugs are normally absorbed into the mesenteric veins that are carried, via the hepatic portal vein, to the liver, and then they enter into the systemic circulatory system via the heart. It might be possible that injected $L$-EVs in mice immediately enter into the circulatory system. Consistent with this speculation, recent studies reported that fluorescent lipophilic dyelabeled EVs, when treated orally (p.o.), intravenously (i.v.), subcutaneously (s.c.) or intraperitoneally in all cases, are accumulated in many organs in the body, including the brain, liver, and kidney, although accumulation levels vary among different regions. For examples, DiD dye-labeled lung cancer cell (LL-2 cell)-derived EVs i.p. injected in C57BL/6 mice were detected in the brain $24 \mathrm{~h}$ after treatment [55]. Staphylococcus aureus-derived EVs [56] or Helicobacter pylori-derived EVs $(100 \mu \mathrm{g} / 100 \mu \mathrm{l})$ [57] treated in C57BL/ 6 mice were also found in the brain $24 \mathrm{~h}$ after treatment.

\section{Sirt1 played a role in L-EV-induced increased expression of BDNF and CREB in HT22 cells}

$L$-EV treatment in HT22 cells increased BDNF expression, and this $L$-EV-induced BDNF expression was in part mediated by Sirt1, but not HDAC2 (Fig. 1). Thus, our results are consistent with the notion that $L$-EVs in HT22 cells induced BDNF expression through a transcriptional mechanism. $L$-EV treatment in CRST-treated mice also increased BDNF and NT4/5 expression in the hippocampus (Fig. 3C and 3D) and these $L$-EV effects were sustained for over 21 days after termination of $L$-EV treatment (Fig. 2C and 3C). These results suggest that $L$-EVs exert persistent changes in the expression of neurotropic factors.

BDNF expression is reduced in the hippocampus of postmortem samples from major depressive disorder patients and in mice with stress-induced depression $[58,59]$. In contrast, depressive behavior is reversed by administration of recombinant BDNF in mice [60]. BDNF expression is regulated by epigenetic factors such as Sirt1, HDACs and MeCP2 in stress-induced depression models $[61,62]$. Sirtl has a deacetylase activity [48]. Sirt1 indirectly regulates BDNF and CREB expression by decreasing miR134 expression $[48,63]$. Sirt 1 can promote axon development and dendritic arborization [63-65]. Sirt1 expression is conversely regulated by miRNAs or other factors $[48,63,66]$. Sirtl is reduced in the hippocampus of mice displaying depressive-like behaviors induced by chronic unpredictable mild stress (CUMS), whereas its activation reversed depression-like behaviors [64]. In rats exposed to CUMS, depression-like behaviors were reversed by resveratrol, which increased the expression of Sirt1, CREB, and BDNF in the hippocampus, while decreasing miR-134 [67]. As demonstrated in the present study, Sirt 1 was also reduced in the hippocampus of mice exposed to chronic restraint stress, whereas $L$-EV treatment increased Sirt1 and BDNF (Fig. 2 and 3). Sirt1 inhibition in HT22 cells reduced the expression of $\mathrm{t} B d n f, B d n f 1, B d n f 4$, and $C r e b 1$. Sirt1 inhibition in $L$-EV-treated HT22 cells reduced the expression of Bdnf 4 and Creb1, compared to that of $L$-EV-treated HT22 cells, suggesting that Sirt1 may have a role in $L$-EV-induced upregulation of $B d n f 4$ and $C r e b 1$ (Fig. $1 \mathrm{D}$ and $1 \mathrm{E}$ ). However, $L$-EVinduced increase of $\mathrm{t} B d n f$ and $B d n f 1$ was not completely blocked by siRNA-Sirt1 (Fig. 1D and 1E). These results suggest that $L$-EVs might increase BDNF expression via Sirt1-dependent and Sirt1independent mechanisms. $\mathrm{MeCP} 2$ is an epigenetic factor that can regulate BDNF expression $[68,69]$. It may be worthwhile to examine whether MeCP2 is involved in $L$-EV effects on BDNF expression in neuronal cells.

Which factor contained in $L$-EVs increases the expression of Sirt 1 is not studied in the present study, but it is a challenging question that needs to be solved. EVs contain proteins, lipids, DNAs, RNAs, enzymes, bacterial metabolites, and toxins [70, 71]. The genus Bacteroides secreted EVs containing glycosidases and proteases that digested glycans which was used for growth [72]. Bacteroides fragilis-derived EVs contained PSA, which prevented colitis by enhancing immunomodulatory effects [73]. EVs derived from Pseudomonas aeruginosa contained bacteria DNAs, which were transferred to lung epithelial cells and were amplified by PCR in the nuclear fraction of cells [74]. Thus, bacterial EVs that contain proteins, lipids, DNA/RNAs, or bacterial metabolites might have a potential to exert physiological effects on host cells. Regarding the dramatic changes in gene expression alteration and behavioral rescues by EVs (Fig. 1 3), the detailed mechanisms how bacteriaderived EVs affect brain function remain to be explored further.

In conclusion, $L$-EV treatment increases the expression of BDNF in hippocampal neurons and produces antidepressant-like effects. Thus, our results support the notion that $L$-EVs and their direct action on neuronal cells mediate antidepressant effects of Lacto- 
bacillus spp.

\section{ACKNOWLEDGEMENTS}

This research was supported by a grant (2018R1A2B2001535) from the Ministry of Science, ICT and Future Planning, Republic of Korea.

\section{REFERENCES}

1. Foster JA, McVey Neufeld KA (2013) Gut-brain axis: how the microbiome influences anxiety and depression. Trends Neurosci 36:305-312.

2. Rogers GB, Keating DJ, Young RL, Wong ML, Licinio J, Wesselingh S (2016) From gut dysbiosis to altered brain function and mental illness: mechanisms and pathways. Mol Psychiatry 21:738-748.

3. Aizawa E, Tsuji H, Asahara T, Takahashi T, Teraishi T, Yoshida S, Ota M, Koga N, Hattori K, Kunugi H (2016) Possible association of Bifidobacterium and Lactobacillus in the gut microbiota of patients with major depressive disorder. J Affect Disord 202:254-257.

4. Kelly JR, Borre Y, O’ Brien C, Patterson E, El Aidy S, Deane J, Kennedy PJ, Beers S, Scott K, Moloney G, Hoban AE, Scott L, Fitzgerald P, Ross P, Stanton C, Clarke G, Cryan JF, Dinan TG (2016) Transferring the blues: depression-associated gut microbiota induces neurobehavioural changes in the rat. J Psychiatr Res 82:109-118.

5. Jiang H, Ling Z, Zhang Y, Mao H, Ma Z, Yin Y, Wang W, Tang W, Tan Z, Shi J, Li L, Ruan B (2015) Altered fecal microbiota composition in patients with major depressive disorder. Brain Behav Immun 48:186-194.

6. Akkasheh G, Kashani-Poor Z, Tajabadi-Ebrahimi M, Jafari P, Akbari H, Taghizadeh M, Memarzadeh MR, Asemi Z, Esmaillzadeh A (2016) Clinical and metabolic response to probiotic administration in patients with major depressive disorder: a randomized, double-blind, placebo-controlled trial. Nutrition 32:315-320.

7. Kato-Kataoka A, Nishida K, Takada M, Kawai M, KikuchiHayakawa H, Suda K, Ishikawa H, Gondo Y, Shimizu K, Matsuki T, Kushiro A, Hoshi R, Watanabe O, Igarashi T, Miyazaki K, Kuwano Y, Rokutan K (2016) Fermented milk containing Lactobacillus casei strain Shirota prevents the onset of physical symptoms in medical students under academic examination stress. Appl Environ Microbiol 82:3649-3658.

8. Bravo JA, Forsythe P, Chew MV, Escaravage E, Savignac HM, Dinan TG, Bienenstock J, Cryan JF (2011) Ingestion of Lac- tobacillus strain regulates emotional behavior and central GABA receptor expression in a mouse via the vagus nerve. Proc Natl Acad Sci U S A 108:16050-16055.

9. McVey Neufeld KA, Kay S, Bienenstock J (2018) Mouse strain affects behavioral and neuroendocrine stress responses following administration of probiotic Lactobacillus rhamnosus JB-1 or traditional antidepressant fluoxetine. Front Neurosci 12:294.

10. Liang S, Wang T, Hu X, Luo J, Li W, Wu X, Duan Y, Jin F (2015) Administration of Lactobacillus helveticus NS8 improves behavioral, cognitive, and biochemical aberrations caused by chronic restraint stress. Neuroscience 310:561-577.

11. Marin IA, Goertz JE, Ren T, Rich SS, Onengut-Gumuscu S, Farber E, Wu M, Overall CC, Kipnis J, Gaultier A (2017) Microbiota alteration is associated with the development of stress-induced despair behavior. Sci Rep 7:43859.

12. Cryan JF, Dinan TG (2012) Mind-altering microorganisms: the impact of the gut microbiota on brain and behaviour. Nat Rev Neurosci 13:701-712.

13. Carabotti M, Scirocco A, Maselli MA, Severi C (2015) The gut-brain axis: interactions between enteric microbiota, central and enteric nervous systems. Ann Gastroenterol 28:203209.

14. Macfarlane S, Macfarlane GT (2003) Regulation of shortchain fatty acid production. Proc Nutr Soc 62:67-72.

15. Nicholson JK, Holmes E, Kinross J, Burcelin R, Gibson G, Jia W, Pettersson S (2012) Host-gut microbiota metabolic interactions. Science 336:1262-1267.

16. Bailey MT, Dowd SE, Galley JD, Hufnagle AR, Allen RG, Lyte M (2011) Exposure to a social stressor alters the structure of the intestinal microbiota: implications for stressor-induced immunomodulation. Brain Behav Immun 25:397-407.

17. Belkaid Y, Hand TW (2014) Role of the microbiota in immunity and inflammation. Cell 157:121-141.

18. Schirmer M, Smeekens SP, Vlamakis H, Jaeger M, Oosting M, Franzosa EA, Ter Horst R, Jansen T, Jacobs L, Bonder MJ, Kurilshikov A, Fu J, Joosten LA, Zhernakova A, Huttenhower C, Wijmenga C, Netea MG, Xavier RJ (2016) Linking the human gut microbiome to inflammatory cytokine production capacity. Cell 167:1125-1136.e8.

19. Desbonnet L, Garrett L, Clarke G, Bienenstock J, Dinan TG (2008) The probiotic Bifidobacteria infantis: an assessment of potential antidepressant properties in the rat. J Psychiatr Res 43:164-174.

20. Lyte M (2011) Probiotics function mechanistically as delivery vehicles for neuroactive compounds: microbial endocrinology in the design and use of probiotics. BioEssays 33:574-581. 
21. Barrett E, Ross RP, O'Toole PW, Fitzgerald GF, Stanton C (2012) $\gamma$-Aminobutyric acid production by culturable bacteria from the human intestine. J Appl Microbiol 113:411-417.

22. Duerkop BA, Vaishnava S, Hooper LV (2009) Immune responses to the microbiota at the intestinal mucosal surface. Immunity 31:368-376.

23. de Lartigue G, de La Serre CB, Raybould HE (2011) Vagal afferent neurons in high fat diet-induced obesity; intestinal microflora, gut inflammation and cholecystokinin. Physiol Behav 105:100-105.

24. Breit S, Kupferberg A, Rogler G, Hasler G (2018) Vagus nerve as modulator of the brain-gut axis in psychiatric and inflammatory disorders. Front Psychiatry 9:44.

25. Ahmadi Badi S, Moshiri A, Fateh A, Rahimi Jamnani F, Sarshar M, Vaziri F, Siadat SD (2017) Microbiota-derived extracellular vesicles as new systemic regulators. Front Microbiol 8:1610.

26. van Niel G, D’Angelo G, Raposo G (2018) Shedding light on the cell biology of extracellular vesicles. Nat Rev Mol Cell Biol 19:213-228

27. Chelakkot C, Choi Y, Kim DK, Park HT, Ghim J, Kwon Y, Jeon J, Kim MS, Jee YK, Gho YS, Park HS, Kim YK, Ryu SH (2018) Akkermansia muciniphila-derived extracellular vesicles influence gut permeability through the regulation of tight junctions. Exp Mol Med 50:e450.

28. Kang CS, Ban M, Choi EJ, Moon HG, Jeon JS, Kim DK, Park SK, Jeon SG, Roh TY, Myung SJ, Gho YS, Kim JG, Kim YK (2013) Extracellular vesicles derived from gut microbiota, especially Akkermansia muciniphila, protect the progression of dextran sulfate sodium-induced colitis. PLoS One 8:e76520.

29. Shen Y, Giardino Torchia ML, Lawson GW, Karp CL, Ashwell JD, Mazmanian SK (2012) Outer membrane vesicles of a human commensal mediate immune regulation and disease protection. Cell Host Microbe 12:509-520.

30. Goffin P, van de Bunt B, Giovane M, Leveau JH, HöppenerOgawa S, Teusink B, Hugenholtz J (2010) Understanding the physiology of Lactobacillus plantarum at zero growth. Mol Syst Biol 6:413.

31. Anjum N, Maqsood S, Masud T, Ahmad A, Sohail A, Momin A (2014) Lactobacillus acidophilus: characterization of the species and application in food production. Crit Rev Food Sci Nutr 54:1241-1251.

32. Paolillo R, Romano Carratelli C, Sorrentino S, Mazzola N, Rizzo A (2009) Immunomodulatory effects of Lactobacillus plantarum on human colon cancer cells. Int Immunopharmacol 9:1265-1271.

33. Tian F, Yu L, Zhai Q, Xiao Y, Shi Y, Jiang J, Liu X, Zhao J, Zhang
H, Chen W (2017) The therapeutic protection of a living and dead Lactobacillus strain against aluminum-induced brain and liver injuries in C57BL/6 mice. PLoS One 12:e0175398.

34. Davis DJ, Doerr HM, Grzelak AK, Busi SB, Jasarevic E, Ericsson AC, Bryda EC (2016) Lactobacillus plantarum attenuates anxiety-related behavior and protects against stress-induced dysbiosis in adult zebrafish. Sci Rep 6:33726.

35. Dhaliwal J, Singh DP, Singh S, Pinnaka AK, Boparai RK, Bishnoi M, Kondepudi KK, Chopra K (2018) Lactobacillus plantarum MTCC 9510 supplementation protects from chronic unpredictable and sleep deprivation-induced behaviour, biochemical and selected gut microbial aberrations in mice. J Appl Microbiol 125:257-269.

36. Kim MH, Choi SJ, Choi HI, Choi JP, Park HK, Kim EK, Kim MJ, Moon BS, Min TK, Rho M, Cho YJ, Yang S, Kim YK, Kim YY, Pyun BY (2018) Lactobacillus plantarum-derived extracellular vesicles protect atopic dermatitis induced by Staphylococcus aureus-derived extracellular vesicles. Allergy Asthma Immunol Res 10:516-532.

37. Seo JS, Park JY, Choi J, Kim TK, Shin JH, Lee JK, Han PL (2012) NADPH oxidase mediates depressive behavior induced by chronic stress in mice. J Neurosci 32:9690-9699.

38. Kim TK, Han PL (2016) Functional connectivity of basolateral amygdala neurons carrying orexin receptors and melaninconcentrating hormone receptors in regulating sociability and mood-related behaviors. Exp Neurobiol 25:307-317.

39. Han HE, Kim TK, Son HJ, Park WJ, Han PL (2013) Activation of autophagy pathway suppresses the expression of iNOS, IL6 and eell death of LPS-stimulated microglia cells. Biomol Ther (Seoul) 21:21-28.

40. Choi J, Kim JE, Kim TK, Park JY, Lee JE, Kim H, Lee EH, Han PL (2015) TRH and TRH receptor system in the basolateral amygdala mediate stress-induced depression-like behaviors. Neuropharmacology 97:346-356.

41. Kim TK, Kim JE, Choi J, Park JY, Lee JE, Lee EH, Lee Y, Kim BY, Oh YJ, Han PL (2017) Local interleukin-18 system in the basolateral amygdala regulates susceptibility to chronic stress. Mol Neurobiol 54:5347-5358.

42. Park JY, Kim TK, Choi J, Lee JE, Kim H, Lee EH, Han PL (2014) Implementation of a two-dimensional behavior matrix to distinguish individuals with differential depression states in a rodent model of depression. Exp Neurobiol 23:215-223.

43. Maqsood R, Stone TW (2016) The gut-brain axis, BDNF, NMDA and CNS disorders. Neurochem Res 41:2819-2835.

44. Distrutti E, O'Reilly JA, McDonald C, Cipriani S, Renga B, Lynch MA, Fiorucci S (2014) Modulation of intestinal microbiota by the probiotic VSL\#3 resets brain gene expression 
and ameliorates the age-related deficit in LTP. PLoS One 9:e106503.

45. Ait-Belgnaoui A, Colom A, Braniste V, Ramalho L, Marrot A, Cartier C, Houdeau E, Theodorou V, Tompkins T (2014) Probiotic gut effect prevents the chronic psychological stressinduced brain activity abnormality in mice. Neurogastroenterol Motil 26:510-520.

46. Finkbeiner S, Tavazoie SF, Maloratsky A, Jacobs KM, Harris KM, Greenberg ME (1997) CREB: a major mediator of neuronal neurotrophin responses. Neuron 19:1031-1047.

47. Guan JS, Haggarty SJ, Giacometti E, Dannenberg JH, Joseph N, Gao J, Nieland TJ, Zhou Y, Wang X, Mazitschek R, Bradner JE, DePinho RA, Jaenisch R, Tsai LH (2009) HDAC2 negatively regulates memory formation and synaptic plasticity. Nature 459:55-60.

48. Herskovits AZ, Guarente L (2014) SIRT1 in neurodevelopment and brain senescence. Neuron 81:471-483.

49. Jeong H, Cohen DE, Cui L, Supinski A, Savas JN, Mazzulli JR, Yates JR 3rd, Bordone L, Guarente L, Krainc D (2011) Sirt1 mediates neuroprotection from mutant huntingtin by activation of the TORC1 and CREB transcriptional pathway. Nat Med 18:159-165.

50. Han A, Sung YB, Chung SY, Kwon MS (2014) Possible additional antidepressant-like mechanism of sodium butyrate: targeting the hippocampus. Neuropharmacology 81:292-302.

51. Bharwani A, Mian MF, Surette MG, Bienenstock J, Forsythe P (2017) Oral treatment with Lactobacillus rhamnosus attenuates behavioural deficits and immune changes in chronic social stress. BMC Med 15:7.

52. Luo J, Wang T, Liang S, Hu X, Li W, Jin F (2014) Ingestion of Lactobacillus strain reduces anxiety and improves cognitive function in the hyperammonemia rat. Sci China Life Sci 57:327-335.

53. Huang SY, Chen LH, Wang MF, Hsu CC, Chan CH, Li JX, Huang HY (2018) Lactobacillus paracasei PS23 delays progression of age-related cognitive decline in senescence accelerated mouse prone 8 (SAMP8) mice. Nutrients 10:E894.

54. Jung IH, Jung MA, Kim EJ, Han MJ, Kim DH (2012) Lactobacillus pentosus var. plantarum C29 protects scopolamineinduced memory deficit in mice. J Appl Microbiol 113:14981506.

55. Garofalo M, Villa A, Rizzi N, Kuryk L, Mazzaferro V, Ciana P (2018) Systemic administration and targeted delivery of immunogenic oncolytic adenovirus encapsulated in extracellular vesicles for cancer therapies. Viruses 10:558.

56. Choi SJ, Kim MH, Jeon J, Kim OY, Choi Y, Seo J, Hong SW, Lee WH, Jeon SG, Gho YS, Jee YK, Kim YK (2015) Active im- munization with extracellular vesicles derived from Staphylococcus aureus effectively protects against staphylococcal lung infections, mainly via Th1 cell-mediated immunity. PLoS One 10:e0136021.

57. Choi HI, Choi JP,Seo J, Kim BJ, Rho M, Han JK, Kim JG (2017) Helicobacter pylori-derived extracellular vesicles increased in the gastric juices of gastric adenocarcinoma patients and induced inflammation mainly via specific targeting of gastric epithelial cells. Exp Mol Med 49:e330.

58. Yu H, Chen ZY (2011) The role of BDNF in depression on the basis of its location in the neural circuitry. Acta Pharmacol Sin 32:3-11.

59. Duclot F, Kabbaj M (2015) Epigenetic mechanisms underlying the role of brain-derived neurotrophic factor in depression and response to antidepressants. J Exp Biol 218:21-31.

60. Shirayama Y, Chen AC, Nakagawa S, Russell DS, Duman RS (2002) Brain-derived neurotrophic factor produces antidepressant effects in behavioral models of depression. J Neurosci 22:3251-3261.

61. Boulle F, van den Hove DL, Jakob SB, Rutten BP, Hamon M, van Os J, Lesch KP, Lanfumey L, Steinbusch HW, Kenis G (2012) Epigenetic regulation of the BDNF gene: implications for psychiatric disorders. Mol Psychiatry 17:584-596.

62. Fuchikami M, Yamamoto S, Morinobu S, Takei S, Yamawaki S (2010) Epigenetic regulation of BDNF gene in response to stress. Psychiatry Investig 7:251-256.

63. Gao J, Wang WY, Mao YW, Gräff J, Guan JS, Pan L, Mak G, Kim D, Su SC, Tsai LH (2010) A novel pathway regulates memory and plasticity via SIRT1 and miR-134. Nature 466:1105-1109.

64. Abe-Higuchi N, Uchida S, Yamagata H, Higuchi F, Hobara T, Hara K, Kobayashi A, Watanabe Y (2016) Hippocampal sirtuin 1 signaling mediates depression-like behavior. Biol Psychiatry 80:815-826.

65. Li XH, Chen C, Tu Y, Sun HT, Zhao ML, Cheng SX, Qu Y, Zhang S (2013) Sirtl promotes axonogenesis by deacetylation of Akt and inactivation of GSK3. Mol Neurobiol 48:490-499.

66. Ng F, Wijaya L, Tang BL (2015) SIRT1 in the brain-connections with aging-associated disorders and lifespan. Front Cell Neurosci 9:64.

67. Shen J, Xu L, Qu C, Sun H, Zhang J (2018) Resveratrol prevents cognitive deficits induced by chronic unpredictable mild stress: Sirt1/miR-134 signalling pathway regulates CREB/BDNF expression in hippocampus in vivo and in vitro. Behav Brain Res 349:1-7.

68. Zhou Z, Hong EJ, Cohen S, Zhao WN, Ho HY, Schmidt L, Chen WG, Lin Y, Savner E, Griffith EC, Hu L, Steen JA, Weitz 
CJ, Greenberg ME (2006) Brain-specific phosphorylation of MeCP2 regulates activity-dependent Bdnf transcription, dendritic growth, and spine maturation. Neuron 52:255-269.

69. Klein ME, Lioy DT, Ma L, Impey S, Mandel G, Goodman RH (2007) Homeostatic regulation of MeCP2 expression by a CREB-induced microRNA. Nat Neurosci 10:1513-1514.

70. Schwechheimer C, Kuehn MJ (2015) Outer-membrane vesicles from Gram-negative bacteria: biogenesis and functions. Nat Rev Microbiol 13:605-619.

71. Fateh A, Vaziri F, Rahimi Janani F, Ahmadi Badi S, Ghazanfari M, Davari M, Arsang A, Siadat SD (2016) New insight into the application of outer membrane vesicles of Gram-negative bacteria. Vaccine Res 3:1-4.

72. Elhenawy W, Debelyy MO, Feldman MF (2014) Preferential packing of acidic glycosidases and proteases into Bacteroides outer membrane vesicles. MBio 5:e00909-e00914.

73. Mazmanian SK, Round JL, Kasper DL (2008) A microbial symbiosis factor prevents intestinal inflammatory disease. Nature 453:620-625.

74. Bitto NJ, Chapman R, Pidot S, Costin A, Lo C, Choi J, D'Cruze T, Reynolds EC, Dashper SG, Turnbull L, Whitchurch CB, Stinear TP, Stacey KJ, Ferrero RL (2017) Bacterial membrane vesicles transport their DNA cargo into host cells. Sci Rep $7: 7072$. 